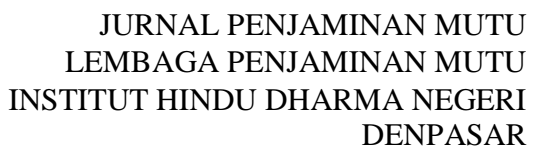

JURNAL PENJAMINAN MUTU

LEMBAGA PENJAMINAN MUTU

INSTITUT HINDU DHARMA NEGERI

DENPASAR

Volume 5 Nomor 2 Agustus 2019

ISSN : 2407-912X (Cetak)

ISSN : 2548-3110 (Online)

http://ejournal.ihdn.ac.id/index.php/JPM

\title{
THE IMPACT OF ONLINE GAME ON THE CHILDREN'S CHARACTER CHANGE
}

\author{
Oleh \\ Gek Diah Desi Sentana, I Wayan Nerta, I Gede Suwindia*, \\ I Putu Oka Agus Mahendradatta \\ Institut Hindu Dharma Negeri Denpasar, Bali, Indonesia \\ *windia_gede@yahoo.com
}

diterima 12 Juni 2019, direvisi 29 Juli 2019, diterbitkan 31 Agustus 2019

\begin{abstract}
Online games are very fast growing lately. The longer, it becomes more fun, including the appearance, style of play, game graphics, image resolution, and so on. There is also a variety of player types such as war, adventure, strategy, fight and all types of online games which are surely interesting to play. The kind of technology development greatly impacts the development of the children's character. When technology is used positively, surely it will help us in our daily life and vice versa. Program (PKM), 1 title Village Partner Development Program (PPDM)
\end{abstract}

\section{Keywords: Online Game; Children's Character}

\section{INTRODUCTION}

The development of human life is not limited to an understanding of growth that is getting bigger. But it also consists of a series of changes that take place continuously and is but from physical and spiritual functions, which the individual possesses toward the stage of maturity through growth, maturation and learning. humans produce forms and characteristics of new abilities that take place from a simple phase of activity to a higher stage. The development moves gradually, but surely, through a form (stage), which is increasingly growing, starting from the moment of conception and end in death.
Of all the phases that occur during the life span, one of the most important phases in individual development is infancy. Called the most important because during this time the individual begins to learn and understand new things and experiences about himself. Many kinds of development tasks must be completed by an individual at this time. Childhood is a period of physical and mental development and growth of children. This period is an introduction to the world to children, children will learn what their parents do.

The development of technology and information which then invite the development of children on the negative side 
increasingly have an impact on the child's daily life, the influence of technology and information is very influential in children's development since he was a child, Information technology is one thing that will not be separated in life human. Because this information technology has been around for centuries and is still developing. Without information technology, people will have difficulty communicating and conveying information. Now information technology is developing so fast along with the development of science. Information and communication technology has many roles and impacts in various fields, especially in entertainment.

Current technological advances cannot be separated from people's lives. Various information that occurs in various parts of the world now we can immediately know thanks to technological advances now the world has felt increasingly narrow because of the rapid access to information in various parts of the world making this world seem increasingly narrower because we can see what is happening in all parts of the world, even though we are in Indonesia.

Of course this technological progress caused a huge change in the lives of humankind with all its civilization and culture. This change also had such a huge impact on the transformation of values in society. Particularly communities with eastern cultures and customs such as Indonesia. in Indonesia we can see so much the influence of technological progress on cultural values that are embraced by society, both urban and rural communities (modernization) technological advancements such as television, telephone and cellphone (cellphone), even the internet not only hit urban communities, but also can be enjoyed by people in remote villages.

In everyday life we cannot escape the changes that occur in the society around us or in ourselves. In discussing about the development of technology basically we cannot escape the development of society itself. Technology is an important part of children's life. The development of a technology will have an impact on the child'ren's growth process.

Almost every tenology has two kinds of impact. The first is a positive impact and the second is a negative impact as well as technological developments. Positive impact created by technology can encourage the birth of a variety of new innovations that facilitate human life and the negative impact of technology can influence the children's social relation (Choi \& Kim, 2004).

Intentionally or not, nowadays all parents prepare their children to face an increasingly developed world, when they begin to utilize a techonology (Moore \& Rideout, 2007). Thus we must monitor what the children is doing. From year to year, the children will obtain information about technology wider, equipment will be more practical, faster, better, and will be cheaper. Children will get easier access to these technologies, especially access to an increasingly sophisticated online game.

Every child is inseparable from play activities, the form of the game also varies from traditional ones which are hereditary to sophisticated games that use machines. Today many millions of children and adolescents enter the digital age through cyberspace life on the internet. The community-entertainment web industry is developing at such a rapid pace. The accounts that become sites for gamepun games are various such as Coc, Poker, Gatrich and many other online games even those that are fond of online games in the form of violence. Most fans of this website are children of school age to students. Online game play is very loved by children this is a new fact that it turns out children are easy targets that many sought after by game makers.

Human creativity in utilizing community technology for entertainment and commercial purposes is indeed extraordinary. Starting from technological developments in the field of television to the creation of video games, video watch, and others. This is because as a form of modernization that we as humans have to 
cope with, we must limit the extent of the negative factors that influence it.

The presence of online games can foster children's and adolescent's appreciation of technology because this game can also stimulate the creativity and reaction of children as long as the child does not play the game repeatedly. The negative impact of this game will be felt when the game can not control themselves. When someone starts to feel, that this game is just to be enjoyed in leisure time as a recreational activity, then the disaster starts.

In every online game, it contains various features that will spoil the players, although basically a game that serves to entertain us in fatigue but in fact it is more than that. When the use of the game exceeds the normal limit, the effect will occur and will continue occuring if it is not stopped $(\mathrm{Ng} \&$ WiemerHastings, 2005). According to detiknet, in psychiatric hospital in Grogol there are four teenagers addicted to game during 2012. Now they still stay in that hospital. One of them is Andi. Actually he is a smart student at school but he could not be separated from his favorite game. Because it is too cool to play the game andi starts to withdraw from his association and often skip school just to play the game. Both of his parents had often banned Andi by taking his smartphone, but the result was that Andi actually went berserk, said Dr. Suzy Yusna Dewi SpKj, head of the Child and Youth Mental Health Installation at Grogol Hospital.

The incident above proves that a game is very dangerous if it is played without parental control and supervision. These habits will affect the children's character starting from actively playing the Game. In fact, game is an application created aiming to reduce the level of stress and anxiety due to routine activities carried out by human beings. But when something is overused, it will take a bad impact as the use of game.

\section{DISCUSSION}

\subsection{Gaming Technology}

The development of technology in this era is very rapid. We can get various technological advancements very easily. Along with the development of the era and the essence of technological development, communication among people can be conducted with various tools or facilities. One of them is a facility to refresh each person such as online games. Games are games that use electronic media, in the form of multimedia that is made as attractive as possible so that players can get inner satisfaction. Games become one of the main cultures and daily activities of the people. Culture of playing games has become a lifestyle that is much favored by the community, especially the younger generation and even children at the elementary school age, both in rural or urban areas.

Online games are very fast growing lately. The longer, the game is more fun, starting from the appearance, style of play, game graphics, image resolution, and so on. There is also a variety of player types such as war players, adventure, strategy, fights and all types of online games which are of course interesting to play. Online games are games that are very popular by children from kindergarten, elementary, junior high and high school. This can be viewed from every children nowadays (Young, 2009).

According to Angela, online game comes from two words, namely game and online. Game that is more defined as something to play and online is defined as connecting to the internet or all game activities connects to the internet (Angela, 2013). So, it can be analyzed online game is a game or game that is connected to an internet so that the players inside can connect with other players and can play together. There are several types of online games played by each person.

a. First Person Shooter (FPS), this game takes first-person views on the game so that as if we were alone in the game or experienced the atmosphere of the game directly, this game mostly took the element of war or military weapons Point Blank, Cross fire and X-Shot. 
b. Real-Time Strategy, This game emphasizes the greatness of strategy of the game players because in this game we become 1 character that we play not in groups for example is Atlantika Online.

c. Browser Games, this game is usually played on browsers like Firefox, Opera, there are some conditions if you want to play this game including the browser supports javascript, php, and flash for example City Ville, Castle Ville, and Ninja Saga.

d. Massive Multiplayer Online Games, this is a game where players play in a world of large scale or a game that can accommodate many players in it, not only that players can interact with each other in which the interaction can be in the form of visual sound or send messages to each other, for example Ragnarok, Luna , Dota, Mobile Lagend, Arena Of Valor

Based on the types of games above, the best-selling game played by children nowadays isthe Mobile Legend. This game is able to attract the heart of children because in this game they can interact with their opponents or their own friends. In addition, this game can be downloaded by every android phone that kids have. The game control is also very easy and not difficult to play. According to Fendy Tan, the Overseas Opration Manager in Indonesia, which was quoted in detikINET "currently, 35 million times the Mobile Legend application has been downloaded and the tone of 8 million daily active users in Indonesia" from the fandy's statement is not wrong when every Indonesian child can play that game.

The development of this technology greatly affects the psychological development of every child. When technology is used positively, every technology will help us in life. For example, the development of technology can make a game become very advanced. The facilities inside are very extraordinary and it will affect the interest of youth to play it. When the advancement of this technology is actually used excessively, this technological progress will not have a positive impact on its users. For example, when the game is not controlled, there will be an addiction effect and lead to psychological disturbance for the player. When there is an unbalanced use of technology, the negative effects will arise on the children.

\subsection{The Influence of Game on the Children's Character}

According to KBBI, character is defined as the psychological nature, morality and character that distinguishes one from other people, habit, and character. Thomas Lickona says character education about being a character, where school is the best place to instill character, while the character education process itself is based on the totality of psychology that covers all individual human potential (cognitive, affective, and psychomotor) and the function of sociocultural totality in the context of interaction in the family of educational units and society (Adisusilo, 2012).

According to Adisusilo, character comes from the Greek "charassein" which means goods or scraping tools, which are later understood as stamps. Or you could say character is something that sticks to someone. The character or nature of a person can be formed, meaning that a person's character can be changed from a positive or negative thing (Adisusilo, 2012).. Although character is an innate element since humans are born as an internal potential of a human being that characterizes differences with other human beings. However, changes in the character of a child can also be influenced by external factors, namely the family, community, social environment, workplace and so on.

In addition, according to Dantes, character is related to moral knowledge, moral feelings and moral behavior. Good character consists of good knowledge, desire to do good or habits to think well, and good behavior habits (Mulyasa, 2011). Based on that point, character education is very important in the family, school and 
community education. In the formal education environment, character education must be given to children in the early childhood, kindergarten, and elementary school. This occurs because at that time it was a sensitive period to receive various forms of good education so that it could be developed to the next level of education, with a foundation of good character education.

But when the children do not live their normal life as carried out above the growth of the character, the children will be disturbed, such as being too addicted to playing the Game, both formal or non-formal education will be ignored by the them. This surely makes the children not get education in their social environment. If it continues occuring, there is no doubt that the case of a child who has experienced a mental disorder because of playing the game very often will occur again.

When a child has experienced a shift in character when playing games often there are some character educations that children will miss. If it is associated with the Lickona's opinion, there are several character educations among them.

a. Moral knowing

Moral knowledge relates to how an individual knows an abstract value that is elaborated in 6 subcomponents, among others, moral awareness, knowledge of moral values, understanding perspectives, moral reasoning, decisions making, and self-understanding

b. Moral feeling

Moral feeling is a stage of behavior in the character component which is elaborated on $6 \mathrm{sub}$, including conscience, self esteem, empathy, love of kindness, self control, and humility

c. Moral Action

Moral behavior is built on 3 components, including competence, desire and habits Viewing from the various moral education above, when a child forgets his moral education because from childhood. $\mathrm{He}$ has focused on the game can be imagined how the child's behavior or how the child's character in addressing his life. Therefore the role of parents is very important in building a child's character from an early age. Basically, Game is a tool to make us happy in playing it, our armpits are even engulfed in the game. When the children are addicted, they will suffer from mental disorder because they ignore their social acitivities.

The development of technology in the era of globalization is very rapid (Prawiradilaga, 2013). The rapid technological development indirectly gives a big influence on human life in various aspects and dimensions (Siregar, 2014). Technology which is a basic human need is supported by the rapid development of science. The development of technology developed drastically and continues to evolve until now and increasingly worldwide. This can be proven by the many innovations and inventions that are simple to very complicated.

\section{CONCLUSION}

Playing games have different levels of addiction for players, namely: sometimes, often, and always. The level of game addiction can be seen from the intensity of the children playing the game. The longer the frequency of playing the game, the more the impact of the game on a child's social personality.

Children's psychology develope both physically and spiritually every day. This appears in spontaneous movements in each of their activity. Every phase experienced by children is a transitional period that exists on them for the direction of the next phase. Chilren in a psychological development must always be accompanied and guided by their parents. Moreover in this era every child has a cellphone which contains online games which look so fun. When it is not controlled by the parents, children will focus on playing and forgetting their social activities. Surely it is dangerous for their psychology when they grow up. 


\section{REFERENCES}

Adisusilo, S. (2012). Pembelajaran NilaiKarakter: Konstruktivisme dan VCT sebagai Inovasi Pendekatan Pembelajaran Afektif. Jakarta: Rajawali Pers.

Angela. (2013). Pengaruh Game Online Terhadap Motifasi belajar siswa SDN 015 Kelurahan Sidomulyo Kecamatan Samarinda Ilir. E-Jurnal Ilmu Komunikasi

Choi, D., \& Kim, J. (2004). Why people continue to play online games: In search of critical design factors to increase customer loyalty to online contents. CyberPsychology \& behavior, 7(1), 1124.

Hiroyuki, A., Juliawan, I. N., \& Sudarsana, I. K. (2018). Internalization Values Of Character Education Towards The Teruna-Daha In The Medi-Median Tradition. Vidyottama Sanatana: International Journal of Hindu Science and Religious Studies, 2(2), 232-238.

Moore, E. S., \& Rideout, V. J. (2007). The online marketing of food to children: is it just fun and games?. Journal of Public Policy \& Marketing, 26(2), 202-220.

Mulyasa. (2011). Manajemen Pendidikan Karakter. Jakarta:PT Bumi Aksara.

Ng, B. D., \& Wiemer-Hastings, P. (2005). Addiction to the internet and online gaming. Cyberpsychology \& behavior, 8(2), 110-113.

Young, K. (2009). Understanding online gaming addiction and treatment issues for adolescents. The American Journal of Family Therapy, 37(5), 355-372.

Prawiradilaga, D.S. dkk. (2013) Mozaik Teknologi Pendidikan E-Learning. Jakarta: Kencana Prenadema Group

Siregar, N. I. (2014). Pengaruh Video Game Berunsur Kekerasan Terhadap Perilaku Agresif Remaja (Kasus Remaja di SMK Wiyata Kharisma, Kecamatan Kemang, Kabupaten Bogor). Bogor: IPB 